\title{
退耕还林还草工程对生态系统碳储存服务的影响 以黄土高原丘陵沟壑区子长县为例
}

\author{
邓元杰 ${ }^{1,2}$,姚顺波 ${ }^{1,2}$, 侯孟阳 ${ }^{1,2}$, 张童越 ${ }^{1}$, 鲁亚楠 ${ }^{1,2}$, \\ 龚直文 ${ }^{1,2}$, 王怡菲 ${ }^{1,2}$
}

(1. 西北农林科技大学经济管理学院, 杨凌 $712100 ; 2$. 西北农林科技大学

资源经济与环境管理研究中心,杨凌 712100)

\begin{abstract}
摘要：陆地生态系统碳储量是表征生态系统碳储存服务的重要指标, 与土地利用变化之间存 在着密切的关系。退耕还林还草工程使区域土地利用格局发生巨大变化,并对生态系统碳储 存服务造成了较大的影响。为了能简单快速的评估退耕还林还草工程对陆地生态系统碳储存 服务所带来的影响, 以位于黄土高原丘陵沟壑区的子长县为例, 运用 InVEST 模型评估了退耕 还林还草工程对陆地生态系统碳储量的影响, 进一步耦合 InVEST模型和FLUS 模型, 并设置四 种不同的退耕还林还草实施情景, 预测子长县 2037 年陆地生态系统碳储量变化和碳汇产生的 经济价值。研究发现: (1)子长县退耕还林还草工程实施效果显著, 17年间共有 $31627.98 \mathrm{hm}^{2}$ 耕地 退耕为林地和草地, 境内的林草覆盖率由 2000 年的 53.26\%增长至 2017 年的 $64.20 \%$; (2)退耕 还林还草工程的实施显著提升了子长县陆地生态系统碳储存服务, 碳储量由 2000 年的 $39.19 \times 10^{6} \mathrm{t}$ 增长至 2017 年 $42.34 \times 10^{6} \mathrm{t}$, 增加量集中在工程实施主要阶段 (2000-2008年); (3)未来子长县若 继续实施退耕还林还草工程, 其生态系统碳储存服务会得到进一步提升, 且会获得一定的碳汇 经济价值。预计到 2037 年子长县在退耕还林还草工程实施 A、B、C、D 四种情景下的陆地生态 系统碳储量将分别达到: $43.78 \times 10^{6} \mathrm{t} 、 44.10 \times 10^{6} \mathrm{t} 、 44.32 \times 10^{6} \mathrm{t}$ 和 $44.54 \times 10^{6} \mathrm{t}$, 并将由此获得碳汇 经济价值净收益分别为 1627.88 万美元、 1979.89 万美元 $、 2231.39$ 万美元和 2471.67 万美元。耦 合 InVEST-FLUS 模型, 不但能利用 InVEST 模型简单快速的对陆地生态系统碳储量进行评估, 而且还能基于 FLUS 模型对未来土地利用变化情景下的陆地生态系统碳储量和碳汇经济价值 做出测算。
\end{abstract}

关键词: 退耕还林还草工程; 陆地生态系统碳储存量; InVEST 模型; FLUS 模型; 子长县

生态系统服务（Ecosystem Services）是人类从生态系统中所获得的各种惠益 ${ }^{[1]}$ 。联 合国在 2005 年发布的千年生态系统评估报告中明确指出生态系统碳储存服务是重要的生 态系统服务之一 ${ }^{[2]}$, 其对受 $\mathrm{CO}_{2}$ 浓度驱动的气候变化具有重要影响, 在调节气候上起着至 关重要的作用 ${ }^{[3]}$ 。而陆地生态系统碳储量作为表征生态系统碳储存服务最重要的指标，其 在全球碳循环中起着非常重要的作用 ${ }^{[4]}$ 。土地利用变化是造成陆地生态系统碳储量变化的 重要因素之一 ${ }^{[5]}$, 土地利用变化使得陆地生态系统原有的土地覆被格局、生态系统结构、 过程和功能都发生改变, 影响着生态系统的物质循环和能量流动 ${ }^{[4,6]}$ 。一方面土地利用变

收稿日期：2018-12-25；修订日期：2019-10-24

基金项目：林业公益性行业科研专项（201504424）；教育部人文社会科学重点研究基地基金项目（14JJD790031）

作者简介：邓元杰（1992-），男，四川内江人，博士研究生，研究方向为资源经济与环境管理。

E-mail: dengyuanjie@nwafu.edu.cn

通讯作者：姚顺波（1964- ), 男，湖南益阳人，博士，教授，研究方向为林业政策评估、资源经济与环境管理。 E-mail: yaoshunbo@163.com 
化会导致陆地生态系统释放出大量的 $\mathrm{CO}_{2}$, 使陆地生态系统逐渐演变成一个巨大的碳 源；另一方面，土地利用变化也能使 $\mathrm{CO}_{2}$ 储存到植被和土壤中，使陆地生态系统的碳汇 能力得到不断增强 ${ }^{[7,8]}$ 。因此, 研究土地利用变化对陆地生态系统碳储量的影响具有十分 重要的意义。

退耕还林还草工程（以下简称 “工程” ）自 1999 年在四川、陕西、甘肃三省试点开 展，再到 2002 年在全国全面启动、 2014 年新一轮工程启动，至今已过了 20 年。黄土高 原地区作为工程实施的核心地区，区内地表覆盖在 20 年来发生了前所未有的大尺度、转 换性改变 ${ }^{[0]}$, 并对陆地生态系统碳循环产生了深远的影响 ${ }^{[10]}$ 。WANG 等 ${ }^{[1]}$ 、姚平等 ${ }^{[1]}$ 分别 以河南省和西南地区的工程建设数据和森林资源清查资料为基础, 建立作物生长模型, 探究工程实施对森林碳储量的影响, 结果表明工程实施使得研究区森林碳汇能力得到了 明显提升; 刘淑娟等 ${ }^{[13]}$ 和赵瑞等 ${ }^{[14]}$ 分别以桂西北典型喀斯特峰丛洼地和广西平果县为 研究区, 运用野外样地调查法, 探究工程实施对植被碳储量的影响, 结果表明工程的实 施使得研究区土壤和植被碳储量均得到了提升。虽然前两种方法在研究中取得了一定的 成果，然而基于清单资料建立作物生长模型对碳储量进行分析，难以实现对空间异质性 问题的定量化研究; 野外样地采样法虽然得到的结果准确, 但是其过程费时费力, 限制 了其在大范围研究区上的应用。为了解决以上问题, 部分学者开始将地理信息系统和遥 感模型用于评估工程实施对陆地生态系统碳储量的影响。如 LIU 等 ${ }^{\left[{ }^{[15}\right.}$ 以全国为研究区, 运用IBIS 模型（Integrated Biosphere Simulator, IBIS）评估工程实施对碳汇的贡献，结果 表明工程实施使得全国的碳汇能力得到了有效提升，并呈现出了一定的空间差异; ZHOU 等 ${ }^{[16}$ 以黄土高原丘陵沟壑区的安塞县为研究区, 运用 GEMS 模型 (General Ensemble Biogeochemical Modeling System, GEMS）评估工程实施对安塞县陆地生态系统碳循 环的影响, 结果表明工程实施有效提升了安塞县的碳汇能力。然而, 虽然运用 IBIS 和 GEMS 模型较好地解决清单资料法和野外样地采样法存在的不足, 但是模型所需输人要 素繁杂, 通用性较差, 弱化了土地利用变化对陆地生态系统碳储量的直接影响。

由美国斯坦福大学、世界自然基金会和大自然保护协会联合开发的 InVEST 模型 (Integrated Valuation of Ecosystem Services and Tradeoffs, InVEST) 由一系列模块和算法 组成, 涵盖多种生态系统服务过程, 其模型中的 Carbon 模块能在空间上直接将土地利用 变化与陆地生态系统碳储量动态变化结合起来，使其既能评估研究区域由过去到现在因 土地利用变化而对陆地生态系统碳储量造成的影响, 还能用于模拟未来土地利用变化情 景下陆地生态系统碳储量的变化。并且由于模块计算所需输人参数简单, 通用性和稳定 性高, 并具有较高可信度, 得以广泛应用于探究土地利用变化对陆地生态系统碳储量的 影响分析中。如徐自为等 ${ }^{[17]}$ 、范立红等 ${ }^{[18]}$ 、郜红娟等 ${ }^{[19]}$ 、张影等 ${ }^{[20]}$ 运用 InVEST 模型研究县 域、流域等不同区域土地利用变化对陆地生态系统碳储量的影响; HE 等 ${ }^{[2]} 、 J I A N G$ 等 $^{[2]} 、$ LYU 等 ${ }^{[23]}$ 和 WANG 等 ${ }^{[24]}$ 则进一步分别将 LUSD-urban、CLUE-S、SLEUTH-3r 和 CA-Markov 模型模拟研究区域未来不同情景下的土地利用变化格局, 并在此基础上耦合 InVEST 模型评估不同情景下由土地利用变化所引起的陆地生态系统碳储量的变化。

从现有的研究来看, 主要存在以下三点亟待拓展的方向。一是国内外鲜有学者使用 InVEST 模型研究由退耕还林还草工程实施所引起的土地利用变化对陆地生态系统碳储量 造成的影响。二是在InVEST 模型与模拟土地利用变化模型进行耦合应用上, 现有研究仅 将模型运用在了未来城市的扩展模拟上，导致了模型模拟时仅考虑了城市扩张，而非多 
种用地类型之间的转换, 忽视了多种土地相互转化过程的相互影响 ${ }^{[25]}$ 。此外, 上述模型 在土地利用预测分配过程中只考虑概率占优的土地利用类型，忽略了土地利用类型间的 相互竞争关系，剔除了非优势土地利用的分配机会，使得模拟结果难以获得与现实土地 利用分布相似的结果 ${ }^{[26-28]}$ 。而FLUS 模型（Future Land Use Simulation Model, FLUS）提 出的一种基于轮盘奢选择的自适应惯性竞争机制, 能够很好地解决上述模型存在的问题 ${ }^{\left[{ }^{28]}\right.}$, 并且 FLUS 模型采用了能够有效处理非线性关系的 ANN 模型，该模型使得土地利用类型 间相互转化的复杂过程变得更为简单 ${ }^{[29]}$, 进而能有效提升多种土地利用类型间的转换概 率，使未来多种土地利用类型在空间上的分布更为准确、合理。三是在陆地生态系统碳 汇服务的经济价值已被广泛认识的全球市场经济形势下 ${ }^{[30]}$, 国内外鲜有学者评估研究区 域在未来某一时段内由土地利用变化产生的碳汇量所带来的社会经济价值。基于此，本 文选择全国退耕还林试点示范县, 位于黄土高原丘陵沟餐区的子长县为例, 基于工程实 施后的四期土地利用数据（2000年、2008年、2013年、2017年)，首先运用InVEST 模型 评估由工程实施所引起的土地利用变化对子长县陆地生态系统碳储量的影响, 其次将 InVEST 模型与 FLUS 模型进行耦合, 评估子长县 2017-2037年土地利用格局在四种不同工 程实施情景影响下的陆地生态系统碳储量潜力和碳汇经济价值。

\section{1 研究方法与数据来源}

\section{1 研究区概况}

子长县位于黄土高原中部, 北依横山, 东接子洲、清涧, 南连延川、延安, 西邻安 塞、靖边, 东西长 $72 \mathrm{~km}$, 南北宽 $55.7 \mathrm{~km}$, 地势由西北向东南倾斜, 海拔 $922 ~ 1563 \mathrm{~m}$, 总面积 $2405 \mathrm{~km}^{2}$ (图 1)。境内属典型的黄土高原丘陵沟壑区, 暖温带半干旱大陆性季风 气候。境内峁梁起伏, 沟譥纵横, 峁梁沟谷地约占总面积的 $94.6 \%$ 。年平均气温 $9.1{ }^{\circ} \mathrm{C}$,

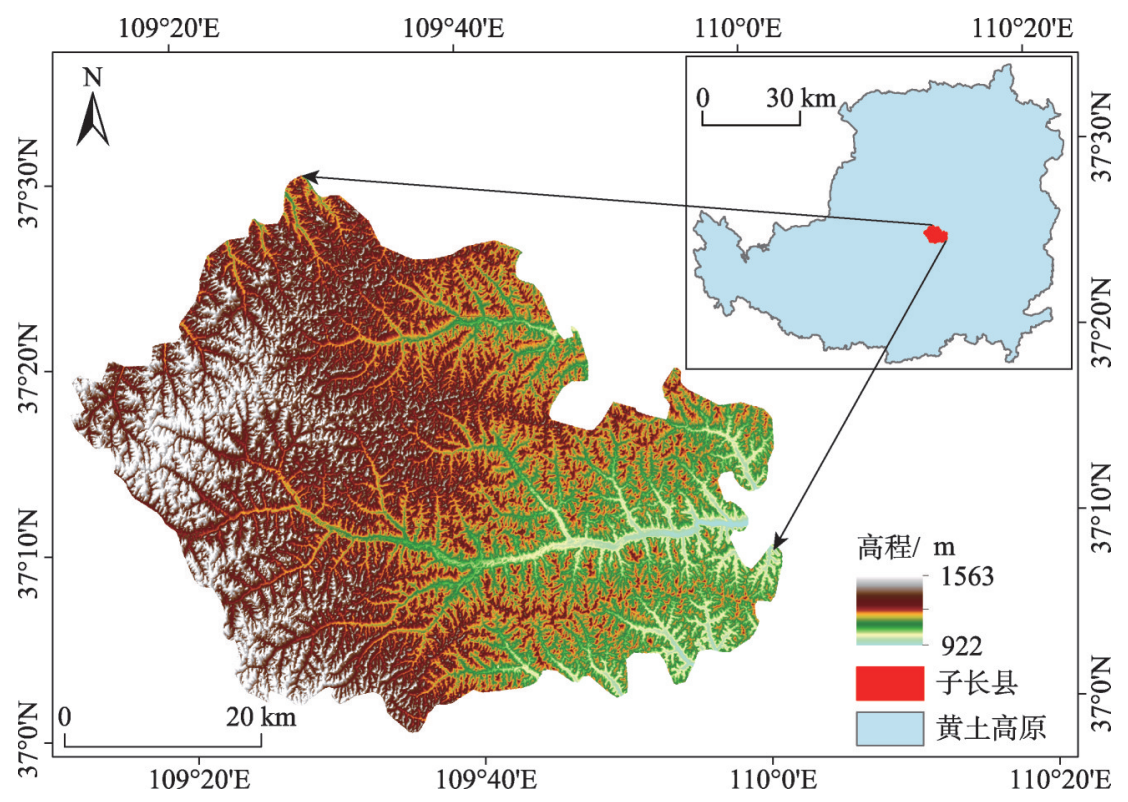

图 1 子长县位置示意图

Fig. 1 Location of Zichang county 
降水量 $514.7 \mathrm{~mm}$ ，无霜期 175 天。有清涧河、无定河、延河三大黄河支流水系。1999年 以来，按照党中央、国务院 “再造一个山川秀美的西部地区” 和 “退耕还林（草）、封山 绿化、个体承包、以粮代赈” 十六字政策措施要求，子长县积极实施退耕还林还草工程 建设，取得了显著成效。

\section{2 数据来源及处理}

本文所使用的子长县 2000 年、 2008 年、2013 年和 2017 年土地利用数据来源于地理 国情监测云平台（http://www.dsac.cn/)，其空间分辨率为 $30 \mathrm{~m}$ ，并根据子长县 4 个时点的土 地利用数据和工程实施的实际情况，将子长县工程分别分为工程主要阶段（2000-2008年）、 工程管护阶段（2008-2013 年）、新一轮工程实施阶段（2013-2017年）。土地利用数据一 级分类结果综合评价精度达到 $94.3 \%$ 以上，二级类型分类综合精度达 $91.2 \%$ 以上 ${ }^{[31]}$ 。本文 土地利用类型根据中国科学院土地利用/覆被标准 ${ }^{[32]}$, 将子长县土地利用类型重新分为 耕地、林地、草地、水域和城乡工矿建设用地五类（图 2)。基础地理信息数据包括子 长县行政边界、道路、铁路、河流、农村居民点来源于国家基础地理信息中心公布的 1：100万全国基础地理数据库（http://www.webmap.cn），子长县 2013 年和 2017 年城乡 工矿建设用地数据提取自子长县同时期土地利用格局图。气象数据来源于中国气象数据 网（http://data.cma.cn/）。高程数据来源于从地理空间数据云（https://www.gscloud.cn/ search）上下载的 ASTER GDEM V2 版本数据，坡度和坡向数据集为基于高程数据使用 ArcGIS 软件计算所得。本文所使用的所有数据空间分辨率均为 $30 \mathrm{~m}$ ，空间坐标系统均为 Krasovsky_1940_Albers。
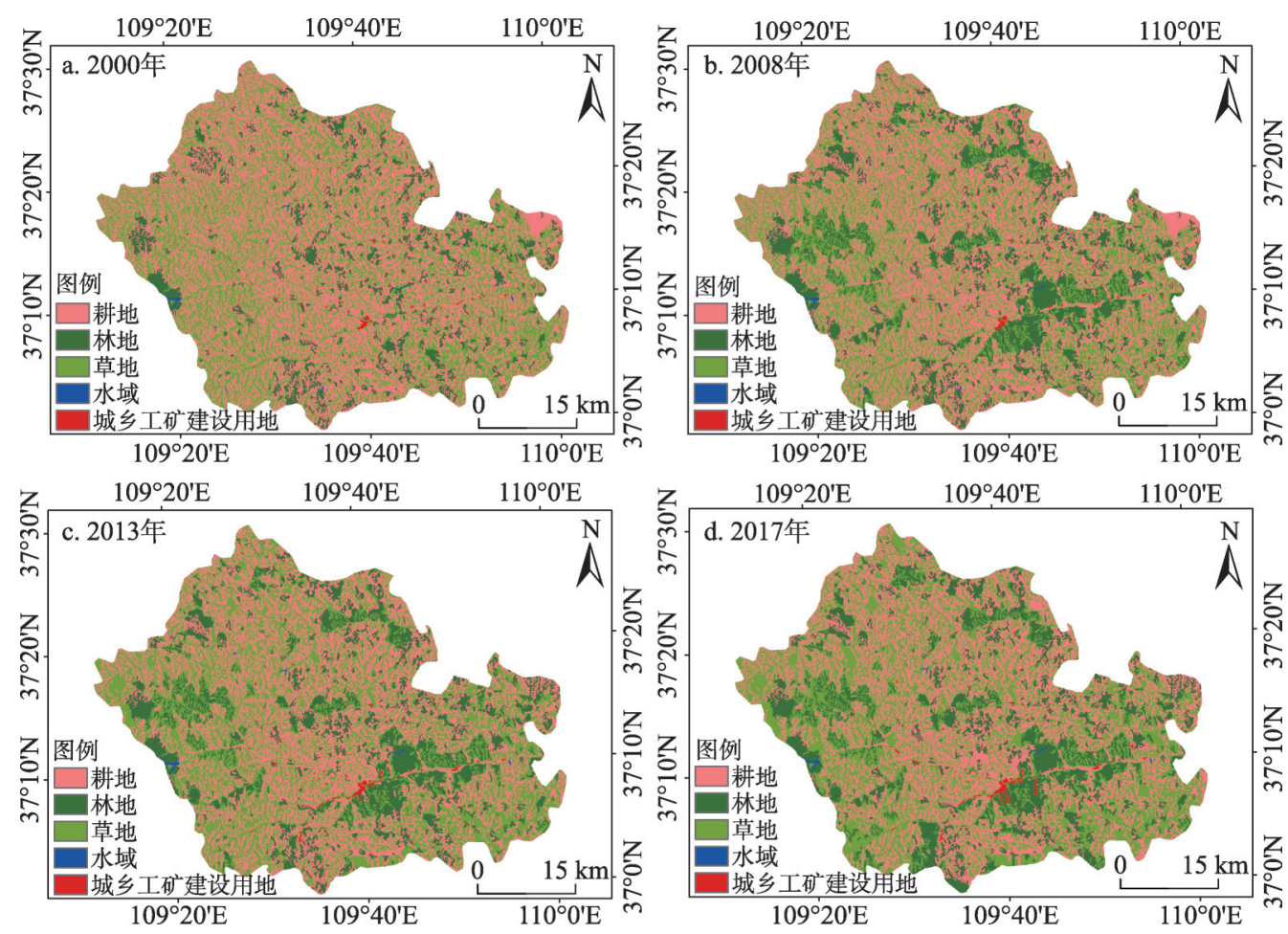

图 22000 年、 2008 年、 2013 年、2017年子长县土地利用类型

Fig. 2 Land use type map of Zichang county in 2000, 2008, 2013 and 2017 


\section{3 研究框架}

本文将InVEST模型和FLUS 模型耦合的基本逻辑框架主要由三大部分组成 ${ }^{[22]}$ (图 3)： （1）设定未来退耕还林还草工程实施情景：运用Markov链为子长县 2017-2037年土地利用 变化设定四种不同的工程实施情景，并求解得到 2037 年子长县在未来四种不同工程实施情 景下的用地类型数量。（2）未来土地利用变化模拟：使用FLUS 模型将四种不同工程实 施情景下的用地类型数量在空间上进行模拟分配，得到子长县 2037 年在四种不同工程实 施情景下的土地利用格局图。（3）陆地生态系统碳储量和碳汇价值评估：运用InVEST模型 首先测算出子长县 2000 年、2008 年、2013 年和 2017 年四期的陆地生态系统碳储量，其 次测算出子长县 2037 年在四种不同工程实施情景下的陆地生态系统碳储量和碳汇价值。

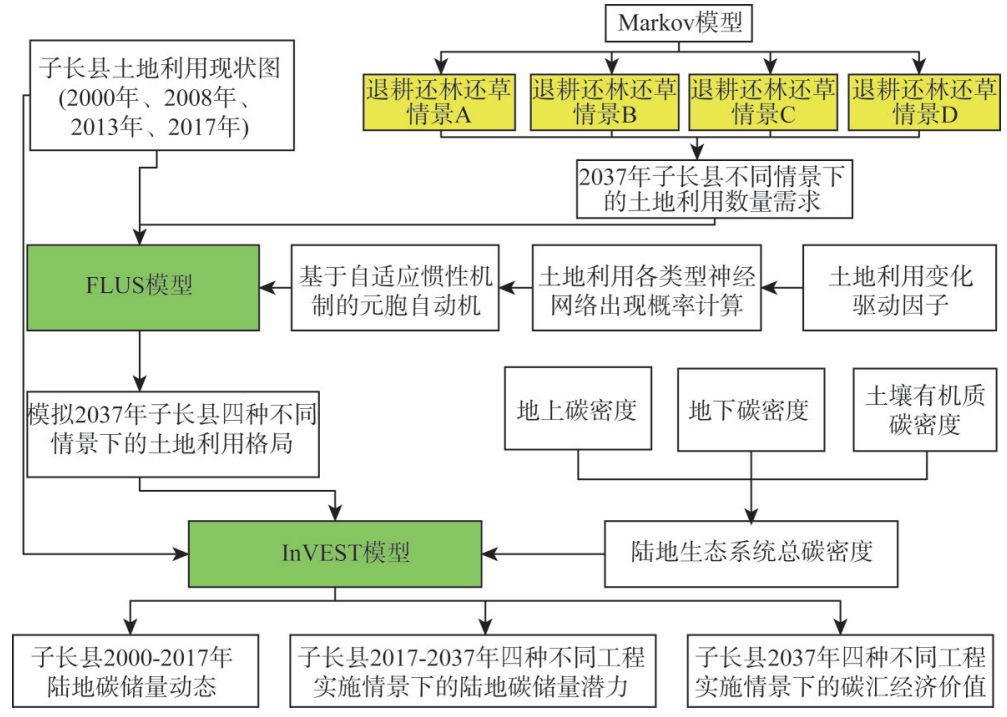

图 3 InVEST-FLUS耦合模型研究框架

Fig. 3 The framework of InVEST-FLUS models

\subsection{Markov 模型}

Markov 模型可以根据事物的一种状态向另外一种状态转化的概率预测未来的状态概 率分布。在土地利用变化研究中, 运用Markov模型, 基于研究区土地利用转移的概率矩 阵，为研究区设定未来的土地利用变化发展情景以及预测各用地类型在相应情景下的数 量已经得到了广泛运用。本文基于子长县 2014-2017年的土地利用转移概率矩阵，通过调 整耕地向林地和耕地向草地的转移概率为子长县设定了四种退耕还林还草工程情景: (1) 退耕还林还草情景 A：保持 2013-2017年土地利用转移矩阵中耕地向林地和草地的转 移概率不变; (2) 退耕还林还草情景 B：将耕地向林地和草地的转移概率分别提高 20\% 和 $10 \%$ ；（3）退耕还林还草情景 C: 将耕地向林地和草地的转移概率分别提高 $35 \%$ 和 20\%；（4）退耕还林还草情景 D：将耕地向林地和草地的转移概率分别提高 50\%和 $30 \%$ 。 Markov模型的表达公式为:

$$
X(k+1)=X(k) \times P
$$

式中: $X(k) 、 X(k+1)$ 分别表示趋势分析与预测对象在 $t=k 、 t=k+1$ 时刻的状态向量 ; $P$ 表示 一步转移概率矩阵。 


\subsection{FLUS 模型}

FLUS 模型主要由两个模块组成，分别为基于神经网络的适宜性概率计算模块和基于 自适应惯性机制的元胞自动机模块。首先，基于子长县 2017 年土地利用类型图和选取的 影响土地利用变化的多种驱动因子，运用FLUS 模型的人工神经网络模块计算出 2037 年 子长县各种用地类型在研究范围内的适宜性概率; 其次, 运用FLUS 模型中的基于轮盘 奢选择的自适应惯性竞争机制解决多种用地类型在自然作用和人类活动共同影响下发生 相互转换的不确定性与复杂性，进而计算出综合规则 ${ }^{[33]}$; 最后，运用FLUS 模型基于该规 则和子长县 2037 年四种不同工程实施情景下的用地类型数量, 运用元胞自动机模拟出四 种不同工程实施情景下的土地利用空间分布格局。

\subsection{1 土地利用变化驱动因子确定}

土地利用变化是各类型土地自身理化条件和自然、社会、经济等内外因共同作用的 结果 ${ }^{[34]}$ 。本文根据子长县实际情况、FLUS 模型的因子需求和研究目的, 主要从影响土地 利用变化的自然因子和社会经济因子两个主要方面出发，选取坡度、坡向、到城镇距 离、到农村居民点距离等共 10 个因素（表1、图4）。

表 1 土地利用变化驱动因子数据说明

Table 1 Data description of driving factors of land use change

\begin{tabular}{|c|c|c|c|c|}
\hline 数据类型 & 数据名称 & 年份 & 数据处理与说明 & 单位 \\
\hline \multirow[t]{5}{*}{ 自然因子 } & 高程 & 2000 & ASTER GDEM V2 & $\mathrm{m}$ \\
\hline & 坡度 & & & $\left({ }^{\circ}\right)$ \\
\hline & 坡向 & & & $\left(^{\circ}\right)$ (方位角) \\
\hline & 年平均气温 & $2013 、 2017$ & 使用 ArcGIA 0.5 软件插值分析工具中 & ${ }^{\circ} \mathrm{C}$ \\
\hline & 年平均降水量 & & 的反距离权重法计算获得 & $\mathrm{mm}$ \\
\hline \multirow[t]{5}{*}{ 社会经济因子 } & 到河流距离 & 2015 & 使用 ArcGIA 0.5 软件距离工具下的欧 & $\mathrm{m}$ \\
\hline & 到铁路距离 & & 氏距离计算获得 & $\mathrm{m}$ \\
\hline & 到公路距离 & & & $\mathrm{m}$ \\
\hline & 到农村居民点距离 & & & $\mathrm{m}$ \\
\hline & 到城镇距离 & 2013、2017 & & $\mathrm{m}$ \\
\hline
\end{tabular}

1.5.2 基于人工神经网络的适宜性概率计算

人工神经网络通常包含输人层、隐藏层、输出层三个隐含层。其具体公式如下:

$$
s p(p, k, t)=\sum_{j} \omega_{j, k} \times \operatorname{sigmoid}\left\{\operatorname{net}_{j}(p, t)\right\}=\frac{\sum_{j} \omega_{j, k}}{1+\mathrm{e}^{-n e t_{j}(p, t)}}
$$

式中: $s p(p, k, t)$ 为第 $k$ 种用地类型在像元 $p$ 、时间 $t$ 上的适宜性概率; $\omega_{j, k}$ 是隐藏层与输出 层间的权值，会在训练中调整； $n e t_{j}(p, t)$ 表示在第 $j$ 个隐藏层输人层神经元在像元 $p$ 、训练 时间 $t$ 上所接收到的信号; $\operatorname{sigmoid}()$ 是隐藏层到输出层的激励函数。对于 ANN 输出的适 宜性概率 $\operatorname{sigmoid}()$ ，在迭代时间 $t$ 像元 $p$ 上，各类用地的适宜性概率的和恒定为 1 , 即:

$$
\sum_{k} s p(p, k, t)=1
$$

\subsection{3 自适应惯性竞争机制}

自适应惯性竞争机制，其核心是自适应惯性系数，每种地类的惯性系数根据现有土 地需求与土地数量的差异决定，并在迭代中自适应调整，从而使各类用地的数量向目标 

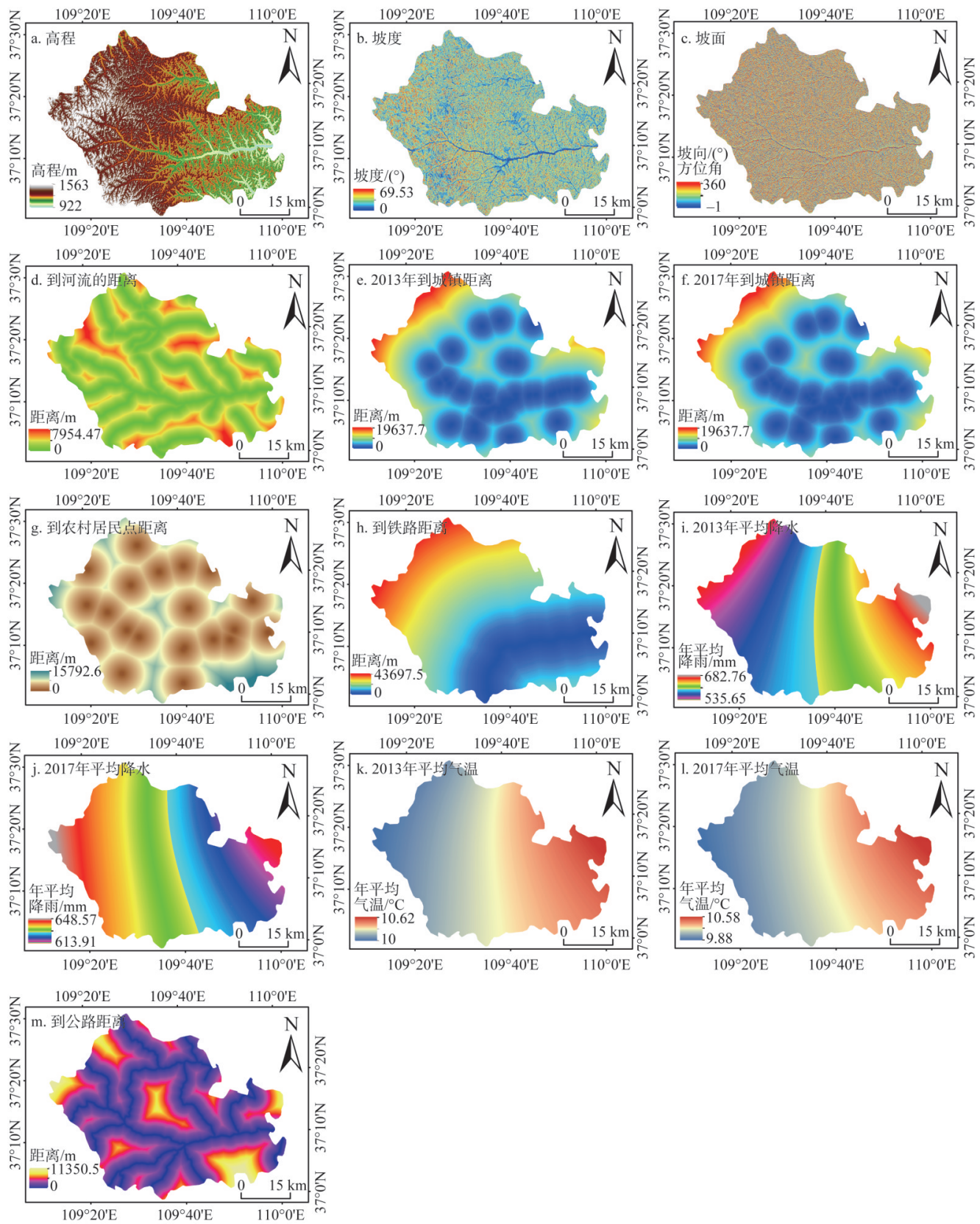

图 4 子长县土地利用变化驱动因子

Fig. 4 Driving trends of land use change in Zichang county

发展 ${ }^{[27,28]}$ 。第 $t$ 种地类在 $l$ 时刻的自适应关系系数 Inertia $_{t}^{l}$ 为:

$$
\text { Inertia }_{t}^{l}=\left\{\begin{array}{cl}
\text { Inertia }_{t}^{l-1} & \left|D_{t}^{l-2}\right| \leqslant\left|D_{t}^{l-1}\right| \\
\text { Inertia }_{t}^{l-1} \times \frac{D_{t}^{l-2}}{D_{t}^{l-1}} & 0>D_{t}^{l-2}>D_{t}^{l-1} \\
\text { Inertia }_{t}^{l-1} \times \frac{D_{t}^{l-1}}{D_{t}^{l-2}} & D_{t}^{l-1}>D_{t}^{l-2}>0
\end{array}\right.
$$


式中: $D_{t}^{l-1} 、 D_{t}^{l-2}$ 分别为 $l-1 、 l-2$ 时刻第 $k$ 种用地类型的栅格数与需求数量之差。

根据以上步骤，分别计算出每个栅格的总概率，通过 CA 迭代，将各用地类型分配 到栅格中。栅格 $p$ 在 $l$ 时刻转化为用地类型 $t$ 的总概率 $T P r o b_{k, t}^{l}$ 可表示为:

$$
\operatorname{TProb}_{k, t}^{l}=P(k, t, l) \times \Omega_{k, t}^{l} \times \text { Inertia }_{t}^{l} \times\left(1-\mathrm{sc}_{c \rightarrow t}\right)
$$

式中： $\mathrm{Sc}_{c \rightarrow t}$ 为土地利用类型 $C$ 转为类型 $T$ 的成本; $1-\mathrm{sc}_{c \rightarrow t}$ 表示发生转化的难易程度; $\Omega_{k, t}^{l}$ 为邻域作用, 其公式为:

$$
\Omega_{k, t}^{l}=\frac{\sum_{N \times N} \operatorname{con}\left(c_{k}^{l-1}=t\right)}{N \times N-1} \times \omega_{t}
$$

式中: $\sum_{N \times N} \operatorname{con}\left(c_{k}^{l-1}=t\right)$ 表示在 $N \times N$ 的 Moore 邻域窗口, 上一次迭代结束后第 $k$ 种地类的 栅格总数; 本文中取 $N=3 ; \omega_{t}$ 为各类用地的邻域作用的权重。

\subsection{4 模型可行性验证}

模型的验证可以用来检验模拟的情况和调整模拟参数，以确保模型可以适用于研究 区域的土地利用变化模拟。本文的模型可行性验证采用Kappa 系数和总体精度（OA）来 验证FLUS 模型的模拟精度。其中, Kappa 系数及 OA 均介于 $0 \sim 1$, 值越接近于 1 , 模拟精 度越好，相反则越差。通常，当 Kappa $>0.5$ 时，模型模拟精度较差；当 $0.5<\mathrm{Kappa} \leqslant 0.75$ 时，模型模拟精度一般; 当 $0.75<\mathrm{Kappa} \leqslant 1$ 时，模型模拟精度较高 ${ }^{[35,36]}$ 。

\subsection{InVEST 模型}

\subsection{1 评估陆地生态系统碳储量和碳流失量}

InVEST 模型中计算陆地生态系统碳储量的 Carbon 模块假设每个土地利用类型生态 系统对应一个由地上生物碳密度、地下生物碳密度、死亡有机质碳密度、土壤有机质碳 库碳密度组成的该地区陆地生态系统的总碳密度 ${ }^{[3]}$ ，但由于死亡有机质碳密度数据难以 获取，故本文仅考虑三大碳库碳储量。碳储量的基本公式为:

$$
\begin{gathered}
C_{i}=C_{i-\text { above }}+C_{i-\text { below }}+C_{i-\text { soil }} \\
C_{\text {tot }}=\sum_{i=1}^{n} C_{i} \times S_{i}
\end{gathered}
$$

式中: $i$ 为某种土地利用类型; $C_{i-\text { above }}$ 为土地利用类型的地上碳密度 $\left(\mathrm{t} / \mathrm{hm}^{2}\right) ; C_{i-\text { below }}$ 为 地下碳储量 $\left(\mathrm{t} / \mathrm{hm}^{2}\right) ; C_{i-\text { soil }}$ 为土壤碳储量 $\left(\mathrm{t} / \mathrm{hm}^{2}\right) ; C_{\text {tot }}$ 为陆地生态系统总的碳储量 $(\mathrm{t}) ; S_{i}$ 为土地利用类型 $i$ 的面积 $\left(\mathrm{hm}^{2}\right) ; n$ 为土地利用类型的数量，本文为 5 。

\section{6 .2 生态系统碳密度数据确定}

根据许泉等 ${ }^{[38]}$ 、解宪丽等 ${ }^{[39]}$ 相关研究，分别获得了全国水平耕地、林地和草地的地 上碳密度; 根据解宪丽等 ${ }^{[39]}$ 研究确定了全国水平耕地、林地和草地的地下碳密度; 根据 李克让 ${ }^{[00]}$ 、马钦彦等 ${ }^{[4]}$ 研究, 确定了全国水平耕地、草地和林地的土壤碳密度; 根据揣 小伟等 ${ }^{[42]}$ 研究得到江苏省水域、城乡工矿建设用地的地上碳密度和土壤碳密度, 地下碳密 度均默认为 0 。然后, 通过参考朱文博等 ${ }^{[43]}$ 和全国气象数据网上提供的数据, 获得全国、 江苏省和子长县多年均温分别为 ${ }^{\circ} \mathrm{C} 、 15.7{ }^{\circ} \mathrm{C} 、 9.64{ }^{\circ} \mathrm{C}$, 降水量分别为 $628 \mathrm{~mm} 、 1040.4 \mathrm{~mm}$ 、 $479 \mathrm{~mm}$ 。最后采用陈光水等 ${ }^{[4]} 、 G i a r d i n a ~$ 等 $^{[45]}$ 、Alam 等 ${ }^{[46]}$ 研究中的关于生物量碳密度和 土壤碳密度分别与气温和降水量的关系模型, 修正得到子长县碳密度数据（表2)。

1.6.3 评估未来不同土地利用情景下的碳汇经济价值

使用InVEST 模型对陆地生态系统碳储量和碳汇量的经济价值进行评估主要由三方面 
构成。首先需要知道当前研究区域所对应 的每吨碳排放的社会成本，第二个是社会 对未来收益更加偏好当前社会直接收益好 处的市场贴现率，第三个是碳价格年际变 化率。在InVEST 模型计算每个栅格中在一 段时间内碳汇的经济价值公式如下：

$$
\begin{aligned}
& \text { value_seq }_{x}=V \frac{\text { sequest }_{x}}{y r_{\text {r f fut }-y r_{-} \text {cur }}} \\
& \sum_{t=0}^{y r_{-} \text {cur }-1} \frac{1}{\left(1+\frac{r}{100}\right)^{t}\left(1+\frac{c}{100}\right)^{t}}
\end{aligned}
$$

表 2 子长县各土地利用类型碳密度

Table 2 Carbon density of different land use types in

\begin{tabular}{lccc}
\multicolumn{3}{c}{ Zichang county } & $\left(\mathrm{t} / \mathrm{hm}^{2}\right)$ \\
\hline 土地利用类型 & $C_{\text {i-above }}$ & $C_{\text {i-below }}$ & $C_{\text {i-soil }}$ \\
\hline 耕地 & 14.47 & 37.08 & 99.45 \\
林地 & 19.48 & 53.25 & 217.33 \\
草地 & 16.22 & 39.74 & 91.74 \\
水域 & 0.02 & 0 & 60.56 \\
城乡工矿建设用地 & 0 & 0 & 54.51 \\
\hline
\end{tabular}

式中：value seq 表示在未来土地利用变化情景中所固碳栅格的碳汇经济价值; $x$ 表示固 碳栅格； $V$ 表示固持每吨碳的价值（美元）； $r$ 表示市场折现率（\%)，反映了社会对当前 收益的偏好，而不是更加偏好于未来的收益； $t$ 表示固持每吨碳的价值年变化率 $(\%)$; $y$ r_cur 表示用于当前土地利用情景下的陆地生态系统碳储量, 本文为 2017 年子长县陆地 生态系统碳储量； yr fut 表示用于计算未来土地利用情景下的陆地生态系统碳储量，本 文为 2037 年子长县四种不同工程实施情景下的陆地生态系统碳储量； sequest 表示当前和 未来土地利用情景下每个栅格中的碳汇量或碳流失量。Ricke 等 ${ }^{[47]}$ 在研究中指出, 当前中 国的碳排放社会成本应该确定为 24美元/t；2017-2037年的碳汇经济价值市场贴现率根据 亚洲发展银行在对项目进行评估时采用 $10 \%$ 12\% 的贴现率 ${ }^{[37]}$, 本文最终将贴现率确定为 $10 \%$ ；碳排放社会成本年际变化率通过参考前人的研究 ${ }^{[48]}$ 将其设置为不变，即为 0 。

\section{2 结果分析}

\section{1 子长县土地利用变化特征}

2000－2017年，受工程实施影响，子长县土地利用变化主要以耕地减少、林地和草地 增加为主要特征, 其中耕地减少 $26892 \mathrm{hm}^{2}$, 林地增加 $23191 \mathrm{hm}^{2}$, 草地增加 $2996 \mathrm{hm}^{2}$, 水域减少 $44 \mathrm{hm}^{2}$, 城乡工矿建设用地增加 $750 \mathrm{hm}^{2}$ 。从工程实施的三个阶段来看，在工程实 施主要阶段（2000-2008年）主要以耕地减少、林地增加为主要特征。这一时期耕地共减少 了 $15922 \mathrm{hm}^{2}$, 为耕地面积减少最多的阶段, 林地共增加 $20299 \mathrm{hm}^{2}$, 为林地面积增加最多 的阶段。工程实施管护阶段（2008-2013年）主要以耕地减少、草地增加为主要特征。耕 地面积继续呈下降趋势，但下降幅度减少，耕地在这一阶段共减少了 $6800 \mathrm{hm}^{2}$ ，草地共 增加了 $5990 \mathrm{hm}^{2}$ ，为草地面积增加最多的阶段。新一轮工程实施阶段（2013-2017年）以 耕地减少，林草地面积增加为主要特征。耕地面积减少了 $4170 \mathrm{hm}^{2}$, 林地和草地面积分 别增加了 $2398 \mathrm{hm}^{2}$ 和 $1440 \mathrm{hm}^{2}$ 。城乡工矿建设用地在三个阶段均呈增加态势, 但是面积 增加主要集中在工程管护阶段 $\left(371 \mathrm{hm}^{2}\right)$ 和新一轮工程实施阶段 $\left(332 \mathrm{hm}^{2}\right)$ ，水域面积 在 3 个阶段变化较小，总体呈小幅下降态势。

依据设置的四种不同工程实施情景下土地利用转移概率矩阵和 2017 年子长县各用地 类型所占土地利用总面积的百分比，运用 Matlab 2016 a 软件计算得到子长县 2037 年在四 种不同工程实施情景下各用地类型数量（表3)。由表3 可得，2017-2037年耕地面积在情 景 $\mathrm{A}$ 下最多, 为 $63974 \mathrm{hm}^{2}$, 而由于受到不同退耕强度的影响，耕地面积在情景 $\mathrm{D}$ 下最 
表 32037 年子长县四种不同退耕还林还草工程实施情景土地类型预测面积

Table 3 Predicted land type of four scenarios of GFGP in Zichang county in 2037

$\left(\mathrm{hm}^{2}\right)$

\begin{tabular}{lccccc}
\hline 退耕还林还草情景 & 耕地 & 林地 & 草地 & 水域 & 城乡工矿建设用地 \\
\hline 2017 年 & 84376 & 47853 & 105885 & 249 & 1111 \\
退耕还林还草情景 A & 63974 & 59570 & 112742 & 230 & 2959 \\
退耕还林还草情景 B & 60920 & 61841 & 113535 & 230 & 2948 \\
退耕还林还草情景 C & 58528 & 63468 & 114310 & 230 & 2939 \\
退耕还林还草情景 D & 56198 & 65025 & 115091 & 230 & 2930 \\
\hline
\end{tabular}

少，预计到 2037 年为 $56198 \mathrm{hm}^{2}$ 。林地和草地在未来 20 年内均呈不断增长态势，其中林 地和草地在情景 A下面积最少, 预计分别为 $59570 \mathrm{hm}^{2}$ 和 $112742 \mathrm{hm}^{2}$, 而在情景 D下将会 达到最多, 预计分别为 $65025 \mathrm{hm}^{2}$ 和 $115091 \mathrm{hm}^{2}$ 。城乡工矿建设用地在未来 20 年内将会 继续保持持续增长态势，其预计数量在情景 $\mathrm{A}$ 下最多，在情景 $\mathrm{D}$ 下最少，然而从整体来 看，2037年城乡工矿建设用地的数量在四种不同的土地利用情景下差异不大。水域在未 来 20 年内，将会呈小幅度下降趋势，预计到 2037 年，水域面积在四种不同工程实施情景 下均为 $230 \mathrm{hm}^{2}$ 。

\subsection{FLUS 模型精度检验及预测模拟}

运用FLUS 模型，基于子长县 2013 年土地利用数据和选取的 10 个土地利用变化驱动 因子，模拟了子长县 2017 年土地利用情景（图 5a），经与 2017 年实际土地利用状况对比 发现 (图 $5 b)$, Kappa 指数为 $0.818, \mathrm{OA}$ 指数为 0.854 , 表明模型精度较高, 可适用于本 文对子长县未来土地利用情景模拟的要求。因此，基于 Markov 模型求解得到的子长县 2037 年四种退耕强度情景下的土地利用数量，运用FLUS 模型，以 2017 年土地利用现状 图为基础，结合选取的 10 个影响土地利用变化的驱动因子，在相应的准则控制下，对 2037年子长县四种退耕情景下的土地利用布局进行模拟（图 5c 图 5f）。
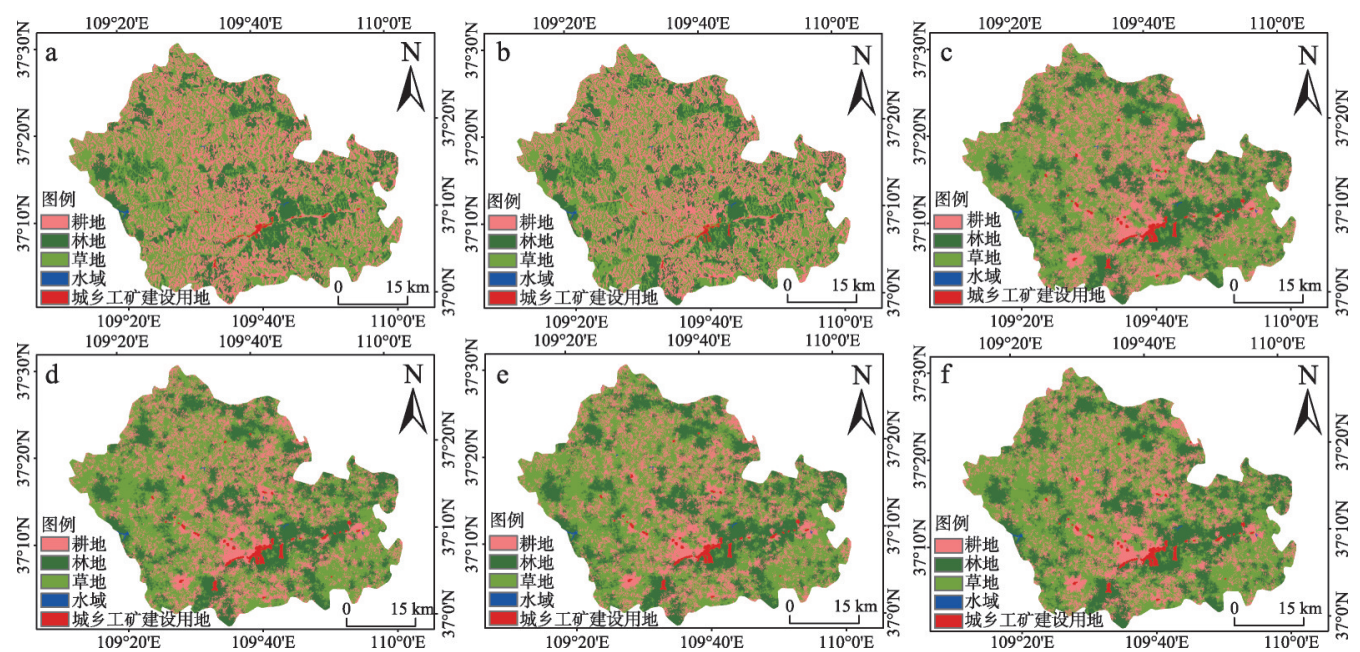

注: $a$ 为 2017 年土地利用情景模拟图, $b$ 为 2017 年土地利用现状图, $c$ 为 2037 年退耕还林还草情景 $A$ 模拟图, $d$ 为 2037 年退耕还林还草情景 B 模拟图, e 为 2037 年退耕还林还草情景 C 模拟图, f 为 2037 年退耕还林还草情景 D模拟图。

图 5 子长县各类型情景模拟

Fig. 5 Scenarios of Zichang county 


\section{3 陆地生态系统碳储量动态变化}

2000 年、2008 年、2013 年和 2017 年子长县四个时期的陆地生态系统碳储量总量分 别为 $39.19 \times 10^{6} \mathrm{t} 、 42.02 \times 10^{6} \mathrm{t} 、 42.04 \times 10^{6} \mathrm{t}$ 和 $42.34 \times 10^{6} \mathrm{t}$ ，地均陆地生态系统碳密度分别 为 $163.65 \mathrm{t} / \mathrm{hm}^{2} 、 175.47 \mathrm{t} / \mathrm{hm}^{2} 、 175.55 \mathrm{t} / \mathrm{hm}^{2}$ 和 $176.79 \mathrm{t} / \mathrm{hm}^{2}$ （图 6)。17年间子长县陆地生 态系统总碳储量呈持续增加趋势，土地利用类型之间的转化促使陆地生态系统碳储量净 增加 $3.15 \times 10^{6} \mathrm{t}$, 增长率为 $8.03 \%$ 。从陆 地生态系统碳储量增加的不同阶段可 得，陆地生态系统碳储量在工程实施主 要阶段（2000-2008年）增长最为显著, 8 年间共净增加 $2.83 \times 10^{6} \mathrm{t}$, 增长率为 $7.23 \%$, 增加量占子长县陆地生态系统 总碳储量增加总量的 $90 \%$ 。然而，陆地 生态系统碳储量在工程实施管护阶段 （2008-2013 年）仅增加了 $0.02 \times 10^{6} \mathrm{t}$ ，增 加率仅为 $0.04 \%$, 增速明显放缓。不过随 着新一轮工程的实施（2013-2017年）, 陆地生态系统碳储量增长了 $0.30 \times 10^{6} \mathrm{t}$, 增加率为 $0.30 \%$, 增速出现上升。

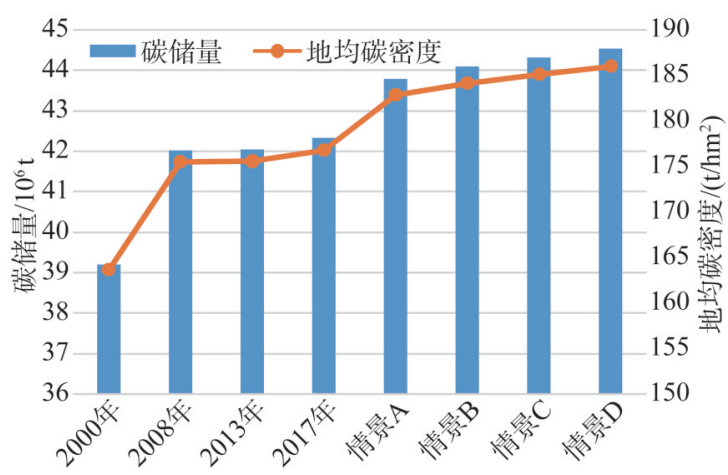

图6 2000-2017年子长县碳储量和 地均碳密度变化

Fig. 6 Variation of carbon storage and average carbon density in Zichang county from 2000 to 2017

从不同土地利用类型碳储量可得，耕地、林地和草地是子长县最为重要的碳库，三 种土地利用类型的固碳总量占所有土地利用类型固碳总量的 $99 \%$ 以上。2015 年，草地为 固碳量最多的地类 $\left(15.99 \times 10^{6} \mathrm{t}\right)$, 林地 $\left(32.73 \times 10^{6} \mathrm{t}\right)$ 和耕地 $\left(29.39 \times 10^{6} \mathrm{t}\right)$ 位列二三 位，城乡工矿建设用地和水域为固碳最少的土地利用类型，分别仅为 $0.14 \times 10^{6} \mathrm{t}$ 和 $0.04 \times 10^{6} \mathrm{t}$ （图 7)。从各土地利用类型的固碳变化趋势可得，退耕还林还草工程实施的 17 年间，耕 地固碳量呈持续下降趋势， 17 年间减少了 $3.97 \times 10^{6} \mathrm{t}$ ，下降率为 $24.17 \%$; 林地城乡工矿建 设用地固碳量均呈上升趋势，17年间固碳量分别增加了 $6.73 \times 10^{6} \mathrm{t}$ 和 $0.04 \times 10^{6} \mathrm{t}$, 增长率分 别为 $94.04 \%$ 和 $207.88 \%$; 草地固碳量呈先减少后增加的趋势，在第一轮工程实施前期碳 储量减少了 $0.67 \times 10^{6} \mathrm{t}$, 而后在第一轮工程实施后期和第二轮工程实施期间碳储量增长了 $1.12 \times 10^{6} \mathrm{t}$; 水域固碳量在 17 年间基本保持不变，为 $0.02 \times 10^{6} \mathrm{t}$ 。

2017-2037年，子长县的陆地生态系 统碳储量在四种工程实施情景下均呈增 长态势, 四种工程实施情景下的陆地生 态系统碳储量在 2037 年将会分别达到 $43.78 \times 10^{6} \mathrm{t}$ ( 情景 A ) $44.10 \times 10^{6} \mathrm{t}$ （情景 B ）、 $44.32 \times 10^{6} \mathrm{t}$ （情景 $\mathrm{C}$ )、 $44.54 \times 10^{6} \mathrm{t}$ (情景 D)，相比于 2017 年分 别依次增长了 $1.45 \times 10^{6} \mathrm{t}$ （情景 $\mathrm{A}$ )、 $1.76 \times 10^{6} \mathrm{t}$ （情景 B ）、1.99 × $10^{6} \mathrm{t}$ （情景

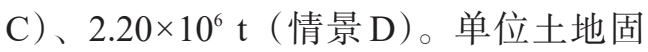
碳能力随着工程的继续施行也得到了不

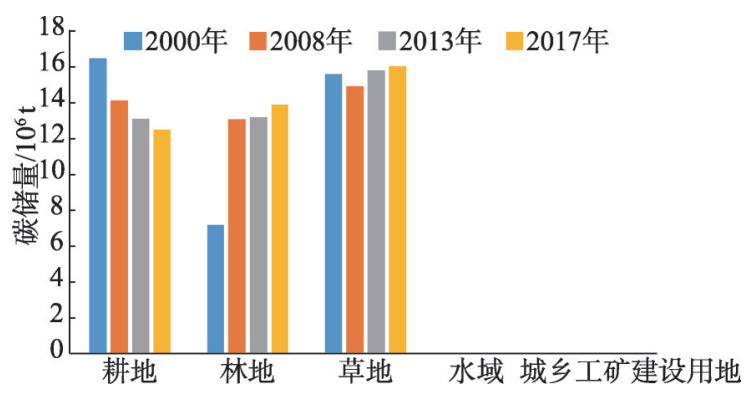

图 72000 - 2017年子长县各土地利用 类型下的碳储量变化

Fig. 7 Carbon storage changes under various land use types in Zichang county, 2000-2017 
断增强, 到 2037 年子长县在四种不同工程实施情景下的地均陆地生态系统碳密度将会依 次分别到达 $182.84 \mathrm{t} / \mathrm{hm}^{2} 、 184.14 \mathrm{t} / \mathrm{hm}^{2} 、 185.08 \mathrm{t} / \mathrm{hm}^{2} 、 185.97 \mathrm{t} / \mathrm{hm}^{2}$ (图 6)。由图 8 可 得, 2017-2037年, 子长县在四种工程实施情景下可分别获得碳汇 $4.31 \times 10^{6} \mathrm{t}$ (情景 $\mathrm{A}$ )、

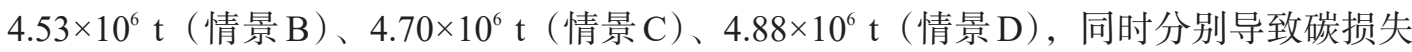

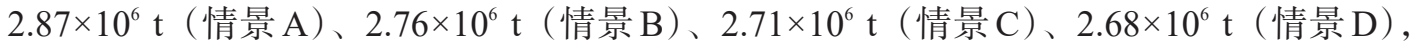
其中由耕地和草地转换为林地为促使陆地生态系统碳储量增加的主要原因, 四种工程实 施情景下由耕地和草地向林地转化可获得的碳汇量分别为 $4.23 \times 10^{6} \mathrm{t}$ (情景 $\mathrm{A}$ )、 $4.44 \times 10^{6} \mathrm{t}$ （情景 B）、4.62 × $10^{6} \mathrm{t} （$ 情景 C )、 $4.80 \times 10^{6} \mathrm{t}$ （情景 D ）, 分别占碳汇总量的 $97.96 \%$ 、 $98.15 \% 、 98.29 \%$ 、98.41\%; 同时, 林地面积减少也是导致碳损失最主要的原因, 四种工 程实施情景下因林地向耕地和草地转化所导致的碳损失量分别为 $2.51 \times 10^{6} \mathrm{t}$ (情景 $\mathrm{A}$ )、

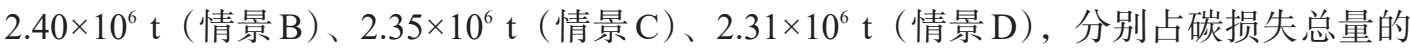
$87.44 \% 、 86.91 \% 、 86.64 \%$ 、86.35\%。

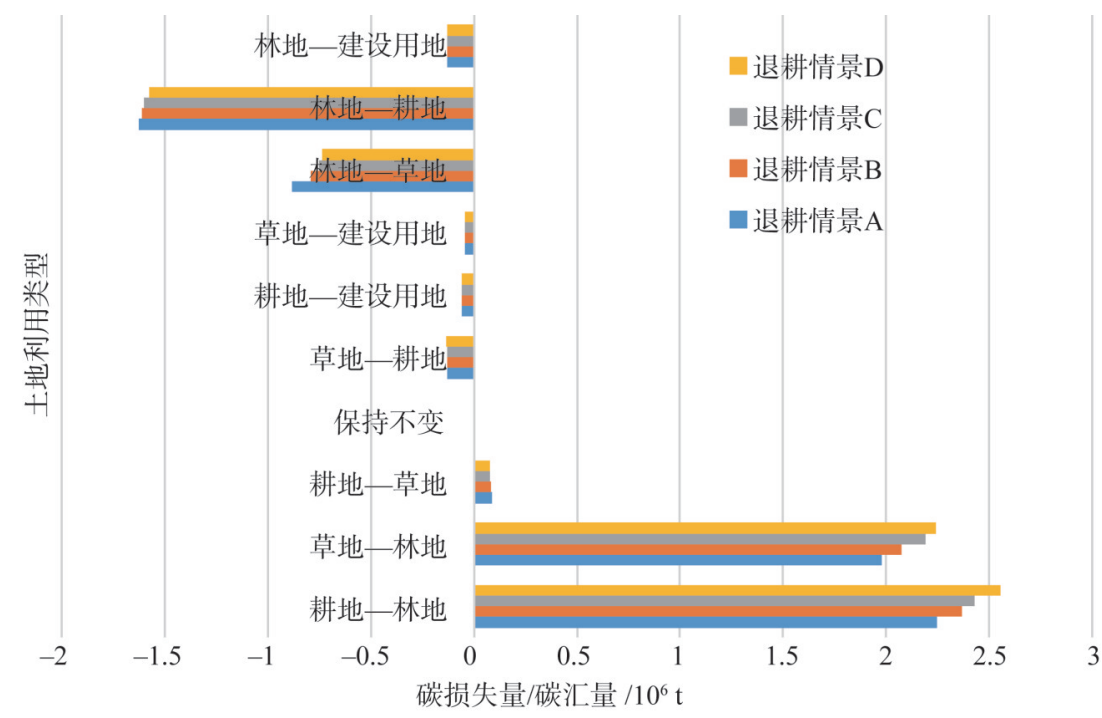

图 8 2017-2037年子长县土地利用转化所引起的陆地生态系统碳储量变化

Fig. 8 Changes of terrestrial ecosystem carbon storage caused by land use transformation in Zichang county from 2017 to 2037

2037 年子长县在四种不同情景下由碳储量增加可获得碳汇经济价值分别为 4847.66 万美元（情景 A）、5085.86万美元（情景 B）、5280.07 万美元（情景 C）和 5480.90 万美 元 (情景 $\mathrm{D})$, 碳损失经济价值分别为 3219.78 万美元 (情景 $A$ )、3105.97万美元 (情景 $B$ )、 3048.68 万美元 (情景 C) 和 3009.23 万美元 (情景 D), 由碳汇经济价值减去碳损失经济 价值即为最终可获得的碳汇经济价值净收益, 2037年子长县在四种工程实施情景下可获 得的碳汇经济价值净收益分别为 1627.88 万美元（情景 $\mathrm{A}$ ）、1979.89 万美元（情景 B）、 2231.39 万美元 (情景 C) 和 2471.67 万美元 (情景 D), 即表明到 2037 年, 子长县在四种 工程实施情景下的土地利用格局将会为子长县分别带来 67.98 美元 $/ \mathrm{hm}^{2} 、 82.68$ 美元 $/ \mathrm{hm}^{2}$ 、 93.18 美元 $/ \mathrm{hm}^{2}$ 和 103.21 美元 $/ \mathrm{hm}^{2}$ 的碳汇经济价值净收益（图9)。

\section{4 退耕还林还草工程对陆地生态系统碳储量的影响}

子长县作为全国退耕还林还草工程示范县，自 1999年工程实施以来，区域内土地利 


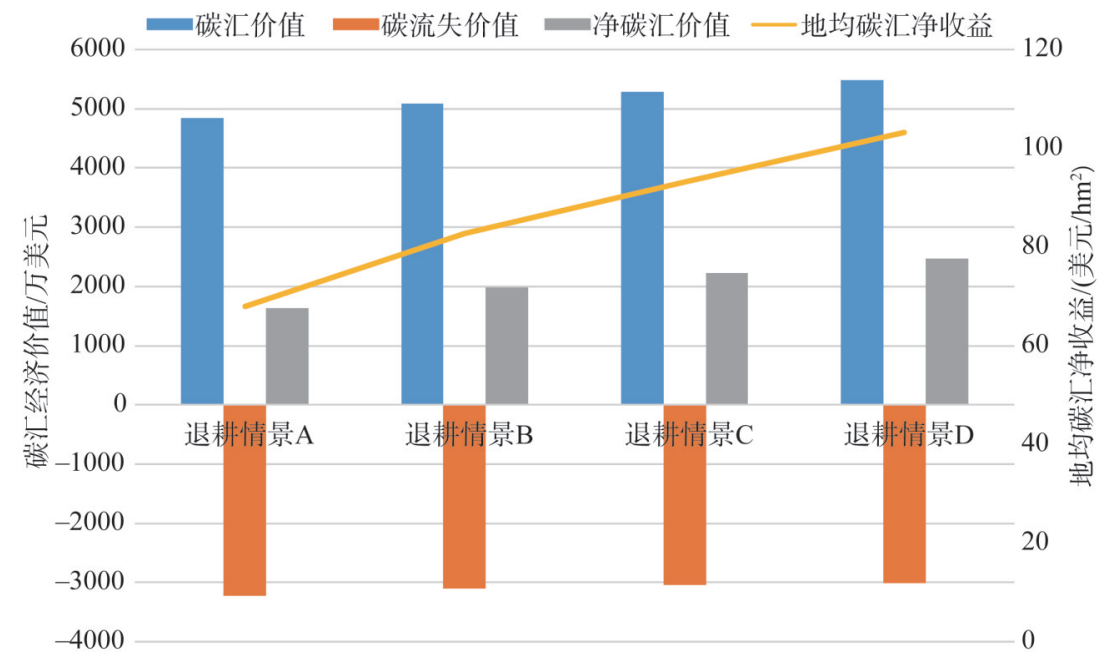

图 92037 年子长县四种不同工程实施情景下的碳汇经济价值

Fig. 9 Economic value of carbon sinks under four project implementation scenarios in Zichang county, 2037

用发生了剧烈变化，并由此对生态系统碳储存服务造成了巨大的影响。2000-2017年，子 长县共退耕 $31627.98 \mathrm{hm}^{2}$, 其中 $19966.95 \mathrm{hm}^{2}$ 耕地退耕为了林地, 促使陆地生态系统碳储 量增加了 $765.81 \times 10^{3} \mathrm{t}, 11661.03 \mathrm{hm}^{2}$ 耕地退耕为草地, 促使陆地生态系统碳储量增加了 $13.64 \times 10^{3} \mathrm{t}$ 。工程 17 年间，县域内林草覆盖率由 2000 年的 $53.26 \%$ 增长至 2017 年的 $64.20 \%$ ，陆地生态系统碳储量由 2000 年的 $39.19 \times 10^{6} \mathrm{t}$ 增长至 2017 年 $42.34 \times 10^{6} \mathrm{t}$, 陆地生 态系统地均碳密度由 $163.65 \mathrm{t} / \mathrm{hm}^{2}$ 增长至 2017 年 $176.79 \mathrm{t} / \mathrm{hm}^{2}$ 。且从不同的退耕时间段来 看，2000-2008年为工程实施强度最大的阶段，也是子长县陆地生态系统碳储量增长最为 快速的阶段, 这一阶段共退耕 $16981.29 \mathrm{hm}^{2}$, 促使子长县陆地生态系统碳储量增加了 $646.53 \times 10^{6} \mathrm{t}$, 且在第一阶段主要以退耕还林为主, 退耕地中 $94 \%$ 退耕为了林地, 使得陆 地生态系统碳储量增加了 $643.41 \times 10^{3} \mathrm{t}$, 仅有 $6 \%$ 耕地退耕为了草地, 使得陆地生态系统 碳储量增加了 $3.11 \times 10^{3} \mathrm{t}$ 。到工程实施管护阶段（2008-2013 年), 退耕强度大幅下降，这 一阶段共退耕 $10160.01 \mathrm{hm}^{2}$, 且这一阶段主要以退耕还草为主, 共还草 $8716.86 \mathrm{hm}^{2}$, 贡 献碳汇量 $9.44 \times 10^{3} \mathrm{t}$, 由此导致退耕面积虽然仅比前一阶段下降了 $40 \%$, 然而碳汇量却在 这一阶段相比上一阶段下降了 $84.53 \%$ 。新一轮工程实施阶段（2013-2017年）共退耕 $4486.68 \mathrm{hm}^{2}$, 贡献了碳汇量 $32.92 \times 10^{3} \mathrm{t}$, 其中退耕还林 $2561.4 \mathrm{hm}^{2}$, 贡献了碳汇量 $31.83 \times 10^{3} \mathrm{t}$, 退耕还草 $1925.28 \mathrm{hm}^{2}$, 贡献了碳汇量 $1.09 \times 10^{3} \mathrm{t}$ 。

由表4可得，2017-2037年，在设定的退耕还林还草情景A下，预计退耕52719.39 $\mathrm{hm}^{2}$, 将会贡献碳汇量 $2335.12 \times 10^{3} \mathrm{t}$, 并产生 2624.19 万美元的经济价值。其中退耕还林 $14228.01 \mathrm{hm}^{2}$, 将会带来 $2247.22 \times 10^{3} \mathrm{t}$ 碳汇, 产生经济价值 2525.40 万美元, 退耕还草 $38491.28 \mathrm{hm}^{2}$, 将会带来 $87.90 \times 10^{3} \mathrm{t}$ 碳汇, 产生经济价值 98.78 万美元。在退耕还林还草 情景 B下，预计退耕 $53921.88 \mathrm{hm}^{2}$, 将会贡献碳汇量 $2450.16 \times 10^{3} \mathrm{t}$, 并产生 2753.47 万美元 的经济价值。其中退耕还林 $14924.97 \mathrm{hm}^{2}$, 将会带来 $2366.31 \times 10^{3} \mathrm{t}$ 碳汇，产生经济价 值 2659.24 万美元, 退耕还草 $38996.91 \mathrm{hm}^{2}$, 将会带来 $83.85 \times 10^{3} \mathrm{t}$ 碳汇, 产生经济价值 94.23 万美元。在退耕还林还草情景 C下, 预计退耕 $54959.67 \mathrm{hm}^{2}$, 将会贡献碳汇量 $2730.11 \times 10^{3} \mathrm{t}$, 并产生 2820.38 万美元的经济价值。其中退耕还林 $15739.56 \mathrm{hm}^{2}$, 将会带 
表 4 子长县退耕还林还草工程对陆地生态系统碳储量的影响

Table 4 Effect of GFGP on carbon storage in terrestrial ecosystem in Zichang county

\begin{tabular}{|c|c|c|c|c|c|c|c|c|}
\hline & $\begin{array}{l}2000 \text { - } \\
2008 \text { 年 }\end{array}$ & $\begin{array}{l}2008 \text { - } \\
2013 \text { 年 }\end{array}$ & $\begin{array}{l}2013 \text { - } \\
2017 \text { 年 } \\
\end{array}$ & $\begin{array}{l}2000 \text { - } \\
2017 \text { 年 }\end{array}$ & $\begin{array}{l}\text { 退耕 } \\
\text { 情景 A } \\
\end{array}$ & $\begin{array}{l}\text { 退耕 } \\
\text { 情景 B }\end{array}$ & $\begin{array}{l}\text { 退耕 } \\
\text { 情景 C } \\
\end{array}$ & $\begin{array}{l}\text { 退耕 } \\
\text { 情景 D } \\
\end{array}$ \\
\hline 退耕还林/hm² & 15962.4 & 1443.15 & 2561.4 & 19966.95 & 14228.01 & 14924.97 & 15739.56 & 16125.12 \\
\hline 退耕还草/hm² & 1018.89 & 8716.86 & 1925.28 & 11661.03 & 38491.38 & 38996.91 & 39220.11 & 40177.26 \\
\hline 退耕总面积/hm² & 16981.29 & 10160.01 & 4486.68 & 31627.98 & 52719.39 & 53921.88 & 54959.67 & 56302.38 \\
\hline 退耕还林贡献碳汇量 $/ 10^{3} \mathrm{t}$ & 643.41 & 90.57 & 31.83 & 765.81 & 2247.22 & 2366.31 & 2429.37 & 2557.37 \\
\hline 退耕还草贡献碳汇量 $/ 10^{3} \mathrm{t}$ & 3.11 & 9.44 & 1.09 & 13.64 & 87.90 & 83.85 & 80.33 & 77.43 \\
\hline 退耕贡献碳汇总量 $/ 10^{3} \mathrm{t}$ & 646.53 & 100.01 & 32.92 & 779.45 & 2335.12 & 2450.16 & 2509.70 & 2634.80 \\
\hline $\begin{array}{l}\text { 退耕还林贡献碳汇经济 } \\
\text { 价值/万美元 }\end{array}$ & 2525.40 & 2659.24 & 2730.11 & 2873.95 & 2525.40 & 2659.24 & 2730.11 & 2873.95 \\
\hline $\begin{array}{l}\text { 退耕还草贡献碳汇经济 } \\
\text { 价值/万美元 }\end{array}$ & 98.78 & 94.23 & 90.28 & 87.02 & 98.78 & 94.23 & 90.28 & 87.02 \\
\hline $\begin{array}{l}\text { 退耕贡献碳汇总价值 } \\
\text { /万美元 }\end{array}$ & 2624.19 & 2753.47 & 2820.38 & 2960.96 & 2624.19 & 2753.47 & 2820.38 & 2960.96 \\
\hline
\end{tabular}

来 $2429.37 \times 10^{3} \mathrm{t}$ 碳汇, 产生经济价值 2730.11 万美元, 退耕还草 $39220.11 \mathrm{hm}^{2}$, 将会带来 $80.3 \times 10^{3} \mathrm{t}$ 碳汇, 产生经济价值 90.28 万美元。在退耕还林还草情景 D下, 预计退耕 $56302.38 \mathrm{hm}^{2}$, 将会贡献碳汇量 $2634.80 \times 10^{3} \mathrm{t}$, 并产生 2820.38 万美元的经济价值。其中 退耕还林 $16125.12 \mathrm{hm}^{2}$, 将会带来 $2557.37 \times 10^{3} \mathrm{t}$ 碳汇, 产生经济价值 2873.95 万美元, 退 耕还草 $40177.26 \mathrm{hm}^{2}$, 将会带来 $77.43 \times 10^{3}$ t碳汇, 产生经济价值 87.02 万美元。

\section{3 结论与讨论}

\section{1 结论}

本文基于退耕还林还草工程实施背景，将FLUS 模型和 InVEST 模型进行耦合，首先 运用 InVEST 模型评估了 2000-2017 年由工程实施所引起的土地利用变化对子长县陆地生 态系统碳储量变化的影响。其次, 运用FLUS 模拟了子长县 2037 年在退耕还林还草情景 A 、退耕还林还草情景 $B$ 、退耕还林还草情景 $\mathrm{C}$ 和退耕还林还草情景 $\mathrm{D}$ 下的土地利用格 局, 然后耦合InVEST 模型评估了四种退耕情景下的陆地生态系统碳储量变化及其所产生 的碳汇经济价值。得到的主要结论如下:

（1） 2000-2017年子长县实施退耕还林还草工程效果显著，17年间共有 $29744.1 \mathrm{hm}^{2}$ 耕 地退耕为林地和草地，境内的林草覆盖率由 2000 年的 53.26\%增长至 2017 年的 $64.20 \%$ 。 工程实施以来, 子长县的陆地生态系统碳储量得到了显著提升, 由 2000 年的 $39.19 \times 10^{6} \mathrm{t}$ 增长至 2017 年的 $42.34 \times 10^{6} \mathrm{t}$; 陆地生态系统地均固碳能力也得到了显著提升, 由 $163.65 \mathrm{t} / \mathrm{hm}^{2}$ 增长至 2017 年的 $176.79 \mathrm{t} / \mathrm{hm}^{2}$ 。

（2）2000-2017年, 退耕还林还草工程的实施共使子长县陆地生态系统碳储量增加了 $779.45 \times 10^{3} \mathrm{t}$, 且主要集中在工程实施主要阶段（2000-2008 年), 陆地生态系统碳储量在 这一阶段共增加了 $646.53 \times 10^{3} \mathrm{t}$, 占增加总量的 $82.95 \%$ 。从退耕还林和退耕还草的碳汇贡 献量来看, 退耕还林是促使子长县生态系统碳储存服务得到提升的主要因素。2000-2017 年, 子长县由退耕还林共使得陆地生态系统碳储量增加了 $765.81 \times 10^{3} \mathrm{t}$, 占增加总量的 $98.25 \%$ ，而退耕还草贡献量仅占 $1.75 \%$ 。2017-2037年，子长县生态系统碳储存服务在四 
种不同的工程实施情景下将会继续得到提升, 其中耕地继续退耕为林地所产生的碳汇量 仍将是促使生态系统碳储存服务提升最主要因素。

（3）2017-2037年，子长县土地利用格局在四种不同的工程实施情景下会继续发生剧 烈变化，但仍集中在耕地、林地和草地三种地类之间。耕地继续退耕为林地和草地将使 得子长县陆地生态系统碳储量继续呈增长态势, 预计到 2037 年子长县陆地生态系统碳储 量在退耕还林还草情景 $\mathrm{A}$ 、退耕还林还草情景 $\mathrm{B}$ 、退耕还林还草情景 $\mathrm{C}$ 和退耕还林还草情 景 D下将会分别达到： $43.78 \times 10^{6} \mathrm{t} 、 44.10 \times 10^{6} \mathrm{t} 、 44.32 \times 10^{6} \mathrm{t}$ 和 $44.54 \times 10^{6} \mathrm{t}$ 。陆地生态系统 地均固碳能力也将得到进一步增强, 在四种情景下将会依次分别达到: $182.84 \mathrm{t} / \mathrm{hm}^{2}$ 、 $184.14 \mathrm{t} / \mathrm{hm}^{2} 、 185.08 \mathrm{t} / \mathrm{hm}^{2} 、 185.97 \mathrm{t} / \mathrm{hm}^{2}$, 并将由此获得碳汇经济价值净收益分别为 1627.88 万美元、 1979.89 万美元、2231.39 万美元和 2471.67 万美元，地均碳汇经济价值 净收益也将分别达到 67.98 美元 $/ \mathrm{hm}^{2} 、 82.68$ 美元 $/ \mathrm{hm}^{2} 、 93.18$ 美元 $/ \mathrm{hm}^{2}$ 和 103.21 美元 $/ \mathrm{hm}^{2}$ 。

（4）本文将FLUS 模型和 InVEST 模型进行耦合，首先能为未来退耕还林还草工程在 空间上的布局实施提供一定的参考价值，进而提升退耕还林还草的实施效率与效果。其 次, 还为日后学者评估其他生态工程的实施对生态系统碳储存服务的影响提供了可供参 考的研究框架。

\section{2 讨论}

本文将FLUS 模型和 InVEST 模型进行耦合，用于评估退耕还林还草工程对陆地生态 系统碳储量的影响，并取得了良好的效果。然而仍存在以下三点可供讨论之处：

（1）虽然在对陆地生态系统碳储量的评估中，InVEST模型以其简单、快速、适用范 围广等优点而在全世界范围内得到了广泛的运用, 并推动了对生态系统碳储存服务研究 的进展。然而, InVEST 模型也存在一定的局限性。首先，InVEST 模型的碳循环原理过 于简化, 研究区土地利用类型的碳库密度被认为是固定不变的, 这就意味着研究区的陆 地生态系统碳储量仅会随着研究时段内土地利用类型面积变化而变化 ${ }^{[49]}$; 并且计算所需 参数均来自于参考前人相关研究, 虽然本文使用气温和降水对研究区域碳库密度进行了 区域修正, 然而仍使得模型结果存在一定的不确定性。在今后的研究中, 应通过实地调 研获取实测数据对碳密度值的合理性进行验证，对研究区域选取的样地进行连续多年监 测, 使得土地利用类型内部空间异质性以及植被年龄结构对碳密度的影响能够得到及时 更新补充 ${ }^{[43]}$, 进而使得 InVEST 模型的评估结果更为准确。

（2）在未来土地利用变化情景设置上，本文的情景设定主要侧重于土地利用数量的 约束, 且运用Markov对未来不同情景下的用地类型数量预测上主要依据土地利用变化的 历史趋势，致使本文在情景的设置和对未来不同情景下用地类型的数量预测中忽略了地 方政府在社会经济政策和土地利用规划政策上对未来土地利用变化的约束和干预 ${ }^{\left[{ }^{5} 0\right]}$ ，因 此在未来的研究中如何结合地方发展政策, 综合考虑研究区自然和社会系统的发展过 程，设置更为贴近现实和符合政策导向下的土地利用发展情景将是未来研究的重点。

(3) 本文在使用FLUS 模型对未来不同的土地利用发展情景进行模拟的驱动因子的 选取上, 虽然从自然和社会两方面选取了共 10 个驱动因子, 然而人口和经济作为影响土 地利用变化最为重要的两个因素, 本文因数据获取的局限性暂未考虑, 可能会减弱人类 活动在模型对模拟用地类型空间分配的影响，导致模拟精度下降。因此，今后在土地利 用变化模拟的驱动因素选择上, 应尽可能地考虑加上人口和经济两大因素, 以提高模型 模拟的精度。 


\section{参考文献(References):}

[1] COSTANZA R, D'ARGE R, DE GROOT R, et al. The value of the world's ecosystem services and natural capital. Nature, 1997, 387(6630): 253-260.

[2] Millennium Ecosystem Assessment. Ecosystems and Human Well-being: Synthesis. Island Press, Washington, D C, 2005.

[3] 蔚芳, 詹小稳. 基于生境质量与碳储量的城市刚性开发边界划定. 浙江大学学报: 工学版, 2019, 53(8): 1478-1487. [WEI F, ZHAN X W. Delineation of rigid urban growth boundary based on habitat quality and carbon storage. Journal of Zhejiang University: Engineering Science, 2019, 53(8): 1478-1487.]

[4] HOUGHTON R A. Revised estimates of the annual net flux of carbon to the atmosphere from changes in land use and land management 1850-2000. Tellus B, 2003, 55(2): 378-390.

[5] HOUGHTON R A. The annual net flux of carbon to the atmosphere from changes in land use 1850-1990. Tellus B, 1999, 51(2): 298-313.

[6] HOUGHTON R A, HACKLER J L. Emissions of carbon from forestry and land-use change in tropical Asia. Global Change Biology, 1999, 5(4): 481-492.

[7] 葛全胜, 戴君虎, 何凡能, 等. 过去 300 年中国土地利用、土地覆被变化与碳循环研究. 中国科学(D辑: 地球科学), 2008, 38(2): 197-210. [GE Q S, DAI J H, HE F N, et al. Study on land use, land cover changes and carbon cycle in China in the past 300 years. Scientia Sinica: Terrae, 2008, 38(2): 197-210.]

[8] 曲福田, 卢娜, 冯淑怡. 土地利用变化对碳排放的影响. 中国人口・资源与环境, 2011, 21(10): 76-83. [QU F T, LU N, FENG S Y. Effects of land use change on carbon emissions. China Population, Resources and Environment, 2011, 21 (10): 76-83.]

[9] 周德成, 赵淑清, 朱超. 退耕还林还草工程对中国北方农牧交错区土地利用/覆被变化的影响: 以科尔沈左翼后旗为 例. 地理科学, 2012, 32(4): 442-449. [ZHOU D C, ZHAO S Q, ZHU C. The impact of the grain for green project on the land use/cover change in the northern farming-pastoral ecotone, China: A case study of Kezuohouqi county. Scientia Geographica Sinica, 2012, 32(4): 442-449.]

[10] DENG L, LIU G, SHANGGUANZ P. Land-use conversion and changing soil carbon stocks in China's 'Grain-for-Green' Program: A synthesis. Global Change Biology, 2014, 20(11): 3544-3556.

[11] WANG Y, LIU L, SHANGGUAN Z P. Carbon storage and carbon sequestration potential under the Grain for Green Program in Henan province, China. Ecological Engineering, 2017, 100: 147-156.

[12] 姚平, 陈先刚, 周永锋, 等. 西南地区退耕还林工程主要林分 50 年碳汇潜力. 生态学报, 2014, 34(11): 3025-3037. [YAO P, CHEN X G, ZHOU Y F, et al. Carbon sequestration potential of the major stands under the Grain for Green Program in Southwest China in the next 50 years. Acta Ecologica Sinica, 2014, 34(11): 3025-3037.]

[13] 刘淑娟, 张伟, 王克林, 等. 桂西北典型喀斯特峰丛洼地退耕还林还草的固碳效益评价. 生态学报, 2016, 36(17): 5528-5536. [LIU S J, ZHANG W, WANG K L, et al. Evaluation of carbon sequestration after conversion of cropland to forest and grassland projection in karst peak-cluster depression area of Northwest Guangxi, China. Acta Ecologica Sinica, 2016, 36(17): 5528-5536.]

[14] 赵瑞, 孙保平, 于明含, 等. 广西壮族自治区平果县退耕还林植被碳储量特征. 水土保持通报, 2015, 35(3): 350-353. [ZHAO R, SUN B P, YU M H, et al. Characters of carbon storage in forests of grain for green project in Pingguo county, Guangxi Zhuang Autonomous Region. Bulletin of Soil and Water Conservation, 2015, 35(3): 350-353.]

[15] LIU D, CHEN Y, CAI W, et al. The contribution of China's Grain to Green Program to carbon sequestration. Landscape Ecology, 2014, 29(10): 1675-1688.

[16] ZHOU D, ZHAO S, LIU S, et al. Modeling the effects of the sloping land conversion program on terrestrial ecosystem carbon dynamics in the Loess Plateau: A case study with Ansai county, Shaanxi province, China. Ecological Modelling, 2014, 288: 47-54.

[17] 徐自为, 张智杰. 基于土地利用变更调查的 2010-2016年新疆尉犁县生态系统碳储量时空变化. 环境科学研究, 2018, 31(11): 1909-1917. [XU Z W, ZHANG Z J. Spatiotemporal variation of carbon storage in Yuli county during 2010-2016. Research of Environmental Sciences, 2018, 31(11): 1909-1917.]

[18] 范立红, 朱建华, 李奇, 等. 三峡库区土地利用/覆被变化对碳储量的影响. 南京林业大学学报: 自然科学版, 2018, 42 (4): 53-60. [FAN L H, ZHU J H, LI Q, et al. Effects of changes in land use and cover on carbon storage in the Three 
Gorges Reservoir Area. Journal of Nanjing Forestry University: Natural Sciences Edition, 2018, 42(4): 53-60.]

[19] 郜红娟, 韩会庆, 张朝琼, 等. 乌江流域贵州段 2000-2010年土地利用变化对碳储量的影响. 四川农业大学学报, 2016, 34(1): 48-53. [GAO H J, HAN H Q, ZHANG C Q, et al. Effects of land use change on carbon storage in Wujiang River of Guizhou province from 2000-2010. Journal of Sichuan Agricultural University, 2016, 34(1): 48-53.]

[20] 张影, 谢余初, 齐姗姗, 等. 基于 InVEST 模型的甘肃白龙江流域生态系统碳储量及空间格局特征. 资源科学, 2016, 38(8): 1585-1593. [ZHANG Y, XIE Y C, QI S S, et al. Carbon storage and spatial distribution characteristics in the Bailongjiang Watershed in Gansu based on In VEST model. Resources Science, 2016, 38(8): 1585-1593.]

[21] HE C, ZHANG D, HUANG Q, et al. Assessing the potential impacts of urban expansion on regional carbon storage by linking the LUSD-urban and InVEST models. Environmental Modelling \& Software, 2016, 75: 44-58.

[22] JIANG W, DENG Y, TANG Z, et al. Modelling the potential impacts of urban ecosystem changes on carbon storage under different scenarios by linking the CLUE-S and the InVEST models. Ecological Modelling, 2017, 345: 30-40.

[23] LYU R, MI L, ZHANG J, et al. Modeling the effects of urban expansion on regional carbon storage by coupling SLEUTH-3r model and InVEST model. Ecological Research, 2019, 34(3): 380-393.

[24] WANG J, ZHANG Q, GOU T, et al. Spatial-temporal changes of urban areas and terrestrial carbon storage in the Three Gorges Reservoir in China. Ecological Indicators. 2018, 95: 343-352.

[25] 朱冠华. 基于高分辨率遥感数据的绿洲区盐化土壤分布变化研究. 北京: 北京交通大学, 2018. [ZHU G H. Monitoring and prediction of salinity soil in oasis based on high-resolution remote sensing data. Beijing: Beijing Jiaotong University, 2018.]

[26] 梁讯. 耦合人类活动与自然效应的土地利用变化模拟(FLUS)的构建与应用. 广州: 中山大学, 2018. [LIANG X. Construction and application of land use change simulation (FLUS) coupled with human activities and natural effects. Guangzhou: Sun Yat-sen University, 2018.]

[27] LI X, CHEN G, LIU X, et al. A new global land-use and land-cover change product at a 1-km resolution for 2010 to 2100 based on human- environment interactions. Annals of the American Association of Geographers, 2017, 107(5): 1040-1059.

[28] LIU X, LIANG X, LI X, et al. A future land use simulation model (FLUS) for simulating multiple land use scenarios by coupling human and natural effects. Landscape and Urban Planning, 2017, 168: 94-116.

[29] LI X, YEH A G. Neural-network-based cellular automaton for simulating multiple land use changes using GIS. International Journal of Geographical Information Science, 2002, 16(4): 323-343.

[30] 彭怡, 王玉宽, 傅斌, 等. 汶川地震重灾区生态系统碳储存功能空间格局与地震破坏评估. 生态学报, 2013, 33(3): 798-808. [PENG Y, WANG Y K, FU B, et al. Spatial distribution of carbon storage function and seismic damage in wenchuan earthquake-stricken areas. Acta Ecologica Sinica, 2013, 33(3): 798-808.]

[31] 刘纪远, 宁佳, 匡文慧, 等. 2010-2015年中国土地利用变化的时空格局与新特征. 地理学报, 2018, 73(5): 789-802. [LIU J Y, NING J, KUANG W H, et al. Spatio-temporal patterns and characteristics of land-use change in China during 2010-2015. Acta Geographica Sinica, 2018, 73(5): 789-802.]

[32] 张景华, 封志明, 姜鲁光. 土地利用/土地覆被分类系统研究进展. 资源科学, 2011, 33(6): 1195-1203. [ZHANG J H, FENG Z M, JIANG L G. Progress on studies of land use/land cover classification systems. Resources Science, 2011, 33 (6): 1195-1203.]

[33] 曹帅, 金晓斌, 杨绪红, 等. 耦合 MOP 与 GeoSOS-FLUS 模型的县级土地利用结构与布局复合优化. 自然资源学报, 2019, 34(6): 1171-1185. [CAO S, JIN X B, YANG H X, et al. Coupled MOP and GeoSOS-FLUS models research on optimization of land use structure and layout in Jintan district. Journal of Natural Resources, 2019, 34(6): 1171-1185.]

[34] 王万茂. 土地利用规划学. 北京: 科学出版社, 2006. [WANG W F. Planning of Land Use. Beijing: Science Press, 2006.]

[35] 权瑞松. 基于情景模拟的上海土地利用变化预测及其水文效应. 自然资源学报, 2018, 33(9): 1552-1562. [QUAN R S. Prediction of land use change and its hydrological effect in Shanghai based on scenario simulation. Journal of Natural Resources, 2018, 33(9): 1552-1562.]

[36] 布仁仓, 常禹, 胡远满, 等. 基于 Kappa 系数的景观变化测度: 以辽宁省中部城市群为例. 生态学报, 2005, (4): 778784. [BU R C, CHANG Y, HU Y M, et al. Measuring spatial information changes using Kappa coefficients: A case 
study of the city groups in central Liaoning province. Acta Ecologica Sinica, 2005, (4): 778-784.]

[37] SHARP R, TALLIS H T, RICKETTS T, et al. InVEST user's guide. The Natural Capital Project: Stanford, CA, USA, 2014.

[38] 许泉, 芮雯奕, 何航, 等. 不同利用方式下中国农田土壤有机碳密度特征及区域差异. 中国农业科学, 2006, (12): 2505-2510. [XU Q, RUI W Y, HE H, et al. Characteristics and regional differences of soil organic carbon density in farmland under different land use patterns in China. Scientia Agricultura Sinica, 2006, (12): 2505-2510.]

[39] 解宪丽, 孙波, 周慧珍, 等. 中国土壤有机碳密度和储量的估算与空间分布分析. 土壤学报, 2004, (1): 35-43. [XIE X L, SUN B, ZHOU H Z, et al. Organic carbon density and storage in soils of China and spatial analysis. Acta Pedologica Sinica, 2004, (1): 35-43.]

[40] 李克让, 王绍强, 曹明奎. 中国植被和土壤碳穴量. 中国科学(D辑: 地球科学), 2003, (1): 72-80. [LI K R, WANG S Q, CAO M K. Carbon storage of vegetation and soil in China. Science in China, Ser. D, 2003, (1): 72-80.]

[41] 马钦彦, 陈遐林, 王娟. 中国北方主要森林类型含碳量的测定. 北京林业大学学报, 2002, 56(24): 96-100. [MA Q Y, CHEN X L, WANG J. Determination of carbon content of major forest types in Northern China. Journal of Beijing Forestry University, 2002, 56(24): 96-100.]

[42] 揣小伟, 黄贤金, 郑泽庆, 等. 江苏省土地利用变化对陆地生态系统碳储量的影响. 资源科学, 2011, 33(10): 19321939. [CHUAI X W, HUANG X J, ZHENG ZE Q, et al. Land use change and itsinfluence on carbon storage of terrestrial ecosystems in Jiangsu province. Resources Science, 2011, 33(10): 1932-1939.]

[43] 朱文博, 张静静, 崔耀平, 等. 基于土地利用变化情景的生态系统碳储量评估: 以太行山淇河流域为例. 地理学报, 2019, 74(3): 446-459. [ZHU W B, ZHANG J J, CUI Y P, et al. Assessment of territorial ecosystem carbon storage based on land use change scenario: A case study in Qihe River Basin. Acta Geographica Sinica, 2019, 74(3): 446-459.]

[44] 陈光水, 杨玉盛, 谢锦升, 等. 中国森林的地下碳分配. 生态学报, 2007, (12): 5148-5157. [CHEN G S, YANG Y S, XIE J S, et al. Total belowground carbon allocation in China's forests. Acta Ecologica Sinica, 2007, (12): 5148-5157.]

[45] GIARDINA C P, RYAN M G. Evidence that decomposition rates of organic carbon in mineral soil do not vary with temperature. Nature, 2000, 404(6780): 858.

[46] ALAM S A, STARR M, CLARK B J. Tree biomass and soil organic carbon densities across the Sudanese woodland savannah: A regional carbon sequestration study. Journal of arid environments, 2013, 89: 67-76.

[47] RICKE K, DROUET L, CALDEIRA K, et al. Country-level social cost of carbon. Nature Climate Change, 2018, 8(10): 895.

[48] ZARANDIAN A, BADAMFIROUZ J, MUSAZADEH R, et al. Scenario modeling for spatial-temporal change detection of carbon storage and sequestration in a forested landscape in Northern Iran. Environmental Monitoring and Assessment, 2018, 190(8): 474.

[49] LIU X, WANG S, WU P, et al. Impacts of urban expansion on terrestrial carbon storage in China. Environmental Science \& Technology, 2019, 53(12): 6834-6844.

[50] 周锐, 苏海龙, 王新军, 等. 基于 CLUE-S 模型和 Markov 模型的城镇土地利用变化模拟预测: 以江苏省常熟市辛庄 镇为例. 资源科学, 2011, 33(12): 2262-2270. [ZHOU R, SU H L, WANG X J, et al. Simulation of land use change in Xinzhuang Town under different scenarios based on the CLUE-S Model and Markov Model. Resources Science, 2011, 33(12): 2262-2270.] 


\title{
Assessing the effects of the Green for Grain Program on ecosystem carbon storage service by linking the InVEST and FLUS models: A case study of Zichang county in hilly and gully region of Loess Plateau
}

\author{
DENG Yuan-jie ${ }^{1,2}$, YAO Shun-bo ${ }^{1,2}$, HOU Meng-yang ${ }^{1,2}, Z_{\text {ZHANG Tong-yue }}^{1}$, \\ LU Ya-nan ${ }^{1,2}$, GONG Zhi-wen ${ }^{1,2}$, WANG Yi-fei ${ }^{1,2}$ \\ (1. College of Economics and Management, Northwest A\&F University, Yangling 712100, Shaanxi, China; \\ 2. Centre for Resource Economic and Environmental Management, Northwest A\&F \\ University, Yangling 712100, Shaanxi, China)
}

\begin{abstract}
Terrestrial carbon storage is an important indicator of ecosystem carbon storage services, and it has a close relationship with land use change. The Green for Grain Program (GFGP) has brought about great changes in the pattern of land use in the region and had a major impact on ecosystem carbon storage services. In order to simply and quickly assess the impact of GFGP on terrestrial ecosystem carbon storage services, this paper takes Zichang county, which is located in the hilly and gully region of the Loess Plateau, as an example, and used InVEST model to assess the impact of GFGP on the carbon storage of terrestrial ecosystems. Moreover, by coupling InVEST model and FLUS model, according to the set A, B, $\mathrm{C}$, and D scenarios of GFGP, the change of terrestrial ecosystem carbon storage and the economic value of carbon sinks in Zichang county in 2037 were predicted. The study found that: (1) Remarkable effect of GFGP in Zichang county occurred. From 2000 to 2017, a total of $31627.98 \mathrm{hm}^{2}$ of cultivated land was converted to woodland and grassland. The forest and grass coverage rates in the study area increased from $53.26 \%$ in 2000 to $64.20 \%$ in 2017 . (2) The carbon storage service of the terrestrial ecosystem was significantly improved from 2000 to 2017. The terrestrial carbon storage increased from $39.19 \times 10^{6} \mathrm{t}$ in 2000 to $42.34 \times 10^{6} \mathrm{t}$ in 2017 , and its growth was mainly found in the main stage of project implementation from 2000 to 2008. (3) In the future, it is assumed that the GFGP will continue to be implemented in the county, and its ecosystem carbon storage services will be further improved. In addition, certain carbon sink economic value will be obtained. Until 2037, it is expected that the terrestrial carbon reserves under the four scenarios of GFGP in the county will reach $43.78 \times 10^{6} \mathrm{t}$ (GFGP scenario

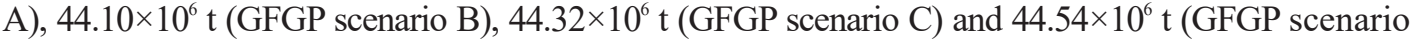
D), respectively. Thus, the net income from the economic value of carbon sinks was US \$ 1627.88 million, US \$ 1979.89 million, US \$ 2231.39 million and US \$ 2471.67 million, respectively. The coupled InVEST-FLUS model can not only use the InVEST model to evaluate land carbon stocks simply and quickly, but also calculate the terrestrial carbon reserves and carbon sink economic value under future land use change scenarios based on the FLUS model.
\end{abstract}

Keywords: Green for Grain Program (GFGP); terrestrial ecosystem carbon storage; InVEST model; FLUS model; Zichang county 